\title{
LEGAL ISSUES \& LANGUAGE LEARNING TECHNOLOGY
}

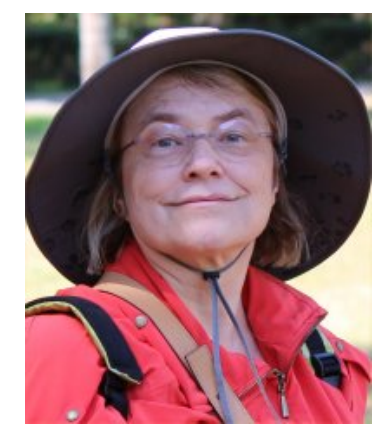

Judy Shoaf

University of Florida

\section{"LAWFULLY MADE UNDER THIS TITLE": THE SINGLE-USE HARD COPY}

Most of us are used to clicking "Accept" or "Agree" on an unread End User License Agreement, assuming that our rights to whatever we are accessing will be limited in some way-in time, in place, in number of potential users. These limits are frustrating if the "whatever" is something we would like to teach with. Perhaps we look for workarounds in order to exercise the distinctly American right of Fair Use.

What if this process were also true of hard copies, books, CDs, and DVDs that happened to have been manufactured outside the U.S.? That is, if the law denied "the principle that ownership of the material object is distinct from ownership of the 
copyright in this material" ${ }^{\prime}$ in these cases, and allowed the copyright owner to control the object itself after selling it?

On Oct. 29, 2012, the Supreme Court heard arguments in Kirtsaeng vs. Wiley, and their ruling is expected as I write this. ${ }^{2}$ The decision they will review, Wiley vs. Kirtsaeng, dates from August 15, 2011, in the Court of Appeals for the 2nd Circuit. The majority opinion in that decision affirmed that "the first sale doctrine does not apply to works manufactured outside of the United States." 3

The first sale doctrine (hereafter First Sale), in U.S. copyright law, is one of many limitations on the rights of copyright holders. Fair Use, vital to educational and scholarly activity, is another of those limitations. Thus this decision has the potential to exclude Fair Use of any copyrighted work if that item was not manufactured in the United States. ${ }^{4}$

First Sale: $§ 109$

$\S 106$ of Title 17 (U.S. copyright law) lists the rights of the copyright holder: to reproduce; prepare derivative works based on; distribute copies to the public by sale or other transfer of ownership, or by rental, lease, or lending; perform or display the copyrighted work publicly (including by means of a digital audio transmission). ${ }^{5}$ However, this list is introduced with an important qualification:

Subject to sections 107 through 122, the owner of copyright under this title has the exclusive rights to do and to authorize any of the following...

$\S 107$ through $\S 122$ specify an abundance of limitations which allow specific individuals and institutions to make use of copyrighted materials, under specific circumstances, without the copyright owner's permission. Some of these exceptions

I wish to thank Christine Fruin, Scholarly Communications Librarian at the University of Florida, for reading an earlier draft of this article and for recommending to me the comment by Benjamin Hamborg, "John Wiley \& Sons, Inc. v. Kirtsaeng: The Uncertain Future of the First-Sale Doctrine," Minnesota Journal of Law, Science, and Technology 13.2 (2012), 899-924, accessed at

http://mjlst.umn.edu/prod/groups/ahc/@pub/@ahc/@mjlst/documents/content/ahc content 396759.pdf.

${ }^{1}$ Columbia Pictures Industries v. Redd Horne, 749 F. 2d 154 - Court of Appeals, 3rd Circuit 1984, par. 35, at http://aw.justia.com/cases/federal/appellate-courts/F2/749/154/359393/. The website

http:/law.justia.com/cases/ is the reference in this article for all cases unless otherwise noted.

${ }^{2}$ Many relevant documents are at http://www.americanbar.org/publications/preview_home/11-697.html

${ }^{3}$ The principal opinion endorsed by Judges Cabranes and Katzmann, p. 20 of the the decision of the $2^{\text {nd }}$ Circuit Court of Appeals. Further references to Wiley vs. Kirtsaeng refer specifically to the $2^{\text {nd }}$ Circuit decision.

${ }^{4}$ Justice Stevens, in his Supreme Court opinion on Quality King vs. L'anza, linked First Sale and Fair Use; he reasoned that if $\$ 602$ got rid of the First Sale limitation on copyright owners' rights for foreign books and magazines, it would also get rid of Fair Use limitations, with results both disastrous and absurd; pp. 13-15, http://www.law.cornell.edu/supct/pdf/96-1470P.ZO.

${ }^{5}$ This is an abbreviation of the original text. It and other citations of copyright law are from http://www.copyright.gov/title17/, chapters 1 and 6. 
are pretty much unique to U.S. law. §107, Fair Use, is vital to education, while $§ 110$ grants the valuable right to use copyrighted works freely in classroom teaching. ${ }^{6}$

First Sale is expressed in $\S 109$. It limits the right to control sale or other transfer of ownership, or ... rental, lease, or lending. The principle was articulated in American courts in 1908 (Bobbs-Merrill Co. v. Straus). First Sale limits the copyright holder's authority over distribution of copies to only the first sale (or other authorized transfer) of the copy. After this first copyright-holder-authorized transfer, the new owner has control over the next transfer:

...the owner of a particular copy or phonorecord lawfully made under this title, or any person authorized by such owner, is entitled, without the authority of the copyright owner, to sell or otherwise dispose of the possession of that copy or phonorecord. $^{7}$

This doctrine is so vital and obvious that it's hard to imagine its contrary. This provision is the basis of the retail (and used) book business, video sales and rental businesses, and the American public library system, as well as any lending library system - the one at your school, for example.

The catch is in the phrase lawfully made under this title. A series of court cases culminating with Wiley vs. Kirtsaeng have sometimes interpreted lawfully made under this title to mean something like "made in the territories where Title 17 is in force," i.e. in the U.S. only.

This would mean that any item made abroad was not protected by First Sale, Fair Use, or the other limitations on copyright owners. At the simplest level, this is a disaster for language teachers and students.

Importing copyrighted items: $§ 602$ vs. $§ 109$

Chapter 6 of Title 17 deals with importing and exporting copyrighted works. This is why the question of where a copyrighted item was made, and/or how it came into this country, is relevant. $\S 602(a)(1)$ is the problematic section: ${ }^{8}$

\footnotetext{
${ }^{6}$ The phrase lawfully made under this title also appears in $§ 110(1)$. In most foreign countries, schools must pay to use video materials in the classroom. American distributors of video would very much like to impose such fees on U.S. schools; educational video distributors in the U.S. typically justify their high prices by including limited rights to show the video in the classroom, a right already guaranteed by U.S. law.

${ }^{7}$ Emphasis added. $§ 109$ immediately goes on to sketch exceptions to First Sale in the case of audio recordings, which cannot be loaned by a library (because of the extreme ease of making a copy) and computer software. ${ }^{8} \S 602(a)(2)$ outlaws the import or export of pirated copies (made without the authority of a U.S. copyright owner) and $\S 602(\mathrm{~b})$ forbids importing pirated items even if the copyright is foreign. The problem, then, is what kind of copies are referred to in $\S 602(a)(1)$.
} 
Importation into the United States, without the authority of the owner of copyright under this title, of copies or phonorecords of a work that have been acquired outside the United States is an infringement of the exclusive right to distribute copies or phonorecords under section $106 \ldots$.

Exceptions are enumerated in $\S 602(a)(3)$ : an individual may bring home one copy of an item purchased abroad for personal use; libraries and government institutions may purchase limited quantities of books and audio materials for "library lending or archival purposes" (though video purchases are restricted to "archival purposes").

$\S 602$ is clearly meant to protect American publishers from competing, perhaps cheaper, foreign editions of their offerings. The sort of situation envisaged is an author's sale of publishing rights to both a British and a U.S. publisher, with the editions printed separately and published at varying prices, on varying dates, in the two countries. ${ }^{9}$

Clearly there is a potential conflict between First Sale (§109) and §602. An importer of books, for instance, would have to be authorized by the foreign publishers. Simply by labeling a CD or DVD "Not for sale outside Canada," the copyright owner could prevent retailers from selling it here. ${ }^{10}$

What, though, is the status of such items after they are brought into the country legally: can the library lend them? Can I give as a gift the DVD I brought home? Can I use it in the classroom?

These questions appear to be absurd.

A sensible interpretation rests on the words "under section 106." $§ 106$ begins by noting that the rights it enumerates are "[s]ubject to sections 107 through 122." Whatever $\S 602$ is supposed to mean, surely it was not designed to "provide greater copyright protection to copies manufactured abroad than those manufactured domestically." 11 Still, if $\S 109$ always trumps $\S 602$, why was $\S 602(a)(1)$ written into the law in the first place?

\footnotetext{
${ }^{9}$ Justice Stevens, in his Quality King vs. L'anza opinion, discussed exactly this situation. The DVD region coding system is an attempt to enforce a similar rule in the theatrical film market.

${ }^{10}$ In the 1908 Bobbs-Merrill case, the publisher had tried to control retail of some books by including a notice that the books could not be sold for less than $\$ 1$. The Supreme Court decided that such a notice did not bind retailers or others after the first sale. Thus the interpretation of $\$ 602$ affects the legal value of this notice on a DVD my language lab owns: "El titular de los derechos patrimoniales de la película contenida solament autoriza su uso privado y doméstico, exclusivamente in México."

${ }^{11}$ Judge Murtha's dissenting opinion in the $2^{\text {nd }}$ Circuit's Wiley vs. Kirtsaeg.
} 
Attempts to harmonize these two sections have most often focused on where the item was manufactured, but as American printing and manufacturing move abroad that has become a dubious guideline. Neither $\S 109$ or $\S 602$ explicitly mentions the place where the copyrighted item was manufactured. In the past 30 years there have been a number of cases in which American courts struggled to harmonize $\S 109$ and $\S 602$. Twice the Supreme Court has had the opportunity to review such cases, both from the $9^{\text {th }}$ Circuit Court of Appeals: Quality King vs. L'anza and Omega vs. Costco. Before looking at these two cases, I want to consider their background.

Gray markets and copyright

When a copyright owner has sued an American distributor for infringement of $\S 602$, the imported goods were not always media items. Consumer goods of any kind (diapers, personal care products, watches) can include a copyrighted label or graphic. "Gray market" cases involve expensive, prestige products which are sold to foreign distributors, and then imported (or re-imported) to the U.S. and re-sold in competition with "authorized" dealers.

An early case of this kind, Sebastian vs. Consumer Contacts, was reviewed in 1988 by the $3^{\text {rd }}$ Circuit Court of Appeals. Sebastian hair products, manufactured in the U.S., carried copyrighted labels, and the company sued a distributor who reimported cut-price products sold for the South Africa market by Sebastian. The court concluded that First Sale protected the importers and re-sellers. They noted however that in a number of earlier cases, lower "courts reasoned that the foreign origin of both manufacture and sale made the first sale doctrine inapplicable," and expressed "uneasiness" about this possibility. ${ }^{12}$ The fact that Sebastian products were made in the U.S., they reasoned, meant that First Sale applied.

The $9^{\text {th }}$ Circuit Court of Appeals, over several cases in the $1990 \mathrm{~s},{ }^{13}$ addressed various permutations of the "gray market." This court evolved the opinion that copyrighted items could only be legally imported with the copyright holder's permission. Once this condition had been met, First Sale operated as usual.

In 1996 the $9^{\text {th }}$ Circuit ruled in L'anza Research vs, Quality King, very similar to the $3^{\text {rd }}$ Circuit's Sebastian case. Whereas earlier $9^{\text {th }}$ Circuit cases involved licensed copies (whether of CDs or labels) produced abroad, L'anza's beauty products were made in the U.S. Here is a summary of 5 cases decided by the two courts:

\footnotetext{
${ }^{12}$ Sebastian International Inc. v. Consumer Contacts, 847 F.2d 1093 ( $3^{\text {rd }}$ Cir. 1988), par. 37 and footnote 1.

${ }^{13}$ BMG Music v.Perez, 952 F.2d 318 (9th Cir. 1991), Parfums Givenchy, Inc. v. Drug Emporium, Inc., 38 F.3d 477 (9th Cir. 1994), Denbicare U.S.A. Inc. v. Toys “ $R$ " Us, Inc., 84 F.3d 1143 ( $9^{\text {th }}$ Cir. 1996), and L'anza Research International Inc. v. Quality King Distributors, Inc 98 F.3d 1109, 40 U.S.P.Q.2d (BNA) 1385 (9th Cir. 1996). All these cases can be viewed at http://law.justia.com/.
} 


\begin{tabular}{|l|l|l|l|l|l|}
\hline & Sebastian & $\begin{array}{l}\text { BMG } \\
\text { Music }\end{array}$ & $\begin{array}{l}\text { Parfubs. } \\
\text { Givenchy }\end{array}$ & Denbicare & Lianza \\
\hline & $1988,3^{\text {sd }}$ & $1991,9^{\text {h }}$ & $1994,9^{\text {h }}$ & $1996,9^{\text {h }}$ & $1996,9^{\text {fh }}$ \\
\hline Item made in US? & Yes & No & No & No & Yes \\
\hline $\begin{array}{l}\text { Import authorized by copyright } \\
\text { holder? }\end{array}$ & No & No & No & Yes & No \\
\hline First Sale applies? & Yes & No & No & Yes & No \\
\hline
\end{tabular}

According to Sebastian, First Sale should have applied in L'anza, because the products were made in the U.S. The $9^{\text {th }}$ Circuit, however, kept to its own rule that what mattered was not where the item was made, but rather whether the import (in this case, re-import) was authorized by the copyright owner. Quality King appealed, and the Supreme Court reviewed the case in 1998.

Quality King vs. L'anza in the Supreme Court: $§ 109$ trumps $§ 602$

The Supreme Court reversed the decision of the $9^{\text {th }}$ Circuit, though it produced two different written opinions as to the issues. All the justices agreed that Quality King had the right to re-import and sell the labeled products under First Sale.

The fact that L'anza's products and labels were made in the U.S. was crucial. As Justice Ginsburg said in her opinion, "we do not today resolve cases in which the allegedly infringing imports were manufactured abroad." ${ }^{14}$ She quoted a copyright manual: "provisions of Title 17 do not apply extraterritorially unless expressly so stated, hence the words 'lawfully made under this title' in the 'first sale' provision, 17 U. S. C. $§ 109(a)$, must mean 'lawfully made in the United States."”

The rest of the judges, while agreeing in favor of the importers Quality King and against L'anza, did not endorse Justice Ginsburg's opinion but rather a separate, longer discussion by Justice Stevens. He was more oblique and willing to qualify his statements, discussing the possible meanings of $\S 109$ and $\S 602$. He finally seems to be saying that the holder of a U.S. copyright might have the right to specify that an item manufactured abroad will not be sold in the U.S. ${ }^{15}$

Omega vs. Costco: $\S 602$ trumps $§ 109 ?$

1n 2008 the $9^{\text {th }}$ Circuit, having had their ideas about how $\S 602$ and $\S 109$ fit together questioned by the Supreme Court in Quality King, faced another "gray

\footnotetext{
${ }^{14}$ Justice Ginsburg's opinion, http://www.law.cornell.edu/supct/pdf/96-1470P.ZC.

${ }^{15}$ Justice Stevens's opinion, p. 11-12. http://www.law.cornell.edu/supct/pdf/96-1470P.ZO.
} 
market" case: a non-copyrightable item (Omega watches) with a copyrighted feature (an engraved design) was being sold in the U.S. by an importer (Costco) without the authority of the copyright holder. The watches were manufactured in Europe and sold by Omega to a European distributor. They had been imported by a third party not authorized to do so by Omega.

The $9^{\text {th }}$ Circuit determined that First Sale did not apply. Costco did not have the right to re-sell the Omega watches. The $9^{\text {th }}$ Circuit emphasized that the item manufactured abroad must also be imported without the copyright holder's authority; if this crucial criterion is met, First Sale applies. Judge Smith, in the $9^{\text {th }}$ Circuit opinion, noted that the court worried about giving "greater copyright protection to foreign-made copies than to their domestically made counterparts.... '[S]uch a result would be untenable.","16

The decision in favor of Omega was appealed to the Supreme Court, which split 4-4 (with one abstention) and did not issue a written opinion. Such a decision failed to establish a federal precedent, though the $9^{\text {th }}$ Circuit decision was still considered valid in the $9^{\text {th }}$ Circuit.

By 2008, of course, the loss of manufacturing jobs in the U.S. was a severe political and economic problem. Since copyright law was being invoked to protect, not creative projects, but consumer goods, the scope of Title 17 was huge. All a manufacturer had to do to control the U.S. market was to be sure that some kind of copyrighted design or text was affixed to the item, and be sure that its manufacture was outsourced. At that point, the manufacturer seemed guaranteed perpetual control.

Wiley vs. Kirtsaeng

This case involves, not labels or designs slapped onto merchandise to invoke copyright protection, but the kind of works - textbooks - that copyright law is meant to protect. In 2007 and 2008, an entrepreneur from Thailand, Supap Kirtsaeng, earned hundreds of thousands of dollars ${ }^{17}$ by selling American students textbooks printed in Asia by John Wiley \& Sons, Inc. These textbooks were substantially the same as the American editions, but much more cheaply produced (think "language lab manual"), and intended for the Asian market. ${ }^{18}$ Kirtsaeng's family bought the

\footnotetext{
${ }^{16}$ Judge Smith, in Omega vs. Costco, citing the problem posed by Parfums Givenchy. pp. 12116-17.

${ }^{17}$ Wiley vs. Kirtsaeng mentions two different figures, $\$ 900,000$ and $\$ 1,250,000$.

${ }^{18}$ As in the 1908 Bobbs-Merrill case, the textbooks included a notice placing conditions on the resale of the book, here "Authorized for sale in Europe, Asia, Africa and the Middle East Only." Bobbs-Merrill's notice was not legally binding (see n. 9 above). This case may decide whether this type of label is binding if the labeled item is manufactured abroad.
} 
books and shipped them to the U.S., where Kirtsaeng sold them in competition with American editions.

When Wiley sued Kirtsaeng, Kirtsaeng raised First Sale as a defense. The Southern District of New York barred this defense, because the books in question had not been manufactured in the United States. Kirtsaeng lost his case and appealed, insisting that he was justified by First Sale.

When the 2nd Circuit Court of Appeals heard the case, the majority opinion defined First Sale as solely dependent on where the books had been printed. They rejected the $9^{\text {th }}$ Circuit's criterion based on whether or not the import had been authorized. Deciding for Wiley against Kirtsaeng, they declared flatly that "the first sale doctrine does not apply to works manufactured outside of the United States."

Judge Murtha, in a dissenting opinion, argued that $§ 109$ always trumps $§ 602$ : "lawfully made under this title" simply means produced in accordance with the provisions of Title 17, no matter where: "the first sale doctrine applies to foreign manufactured copies." He acknowledged the era of globalization : "I do not believe Congress intended to provide an incentive for U.S. copyright holders to manufacture copies of their work abroad." 19 According to his reasoning, First Sale would have applied in all the cases mentioned in this article: no copyright holder can ever restrict the use a U.S. purchaser makes of a particular copy.

The question before the Supreme Court, then, is not just whether Kirtsaeng is guilty, but also the grounds of his guilt. The justices could say that

Kirtsaeng is not guilty; the place of manufacture and purchase is irrelevant to the rights of the current owner (Judge Murtha, $2^{\text {nd }}$ Circuit, dissenting); or

Kirtsaeng is guilty, because Wiley has perpetual authority over the sale or other transfer of ownership, or ... rental, lease, or lending of the Asian-manufactured books. ( $2^{\text {nd }}$ Circuit majority), or

Kirtsaeng is guilty, because two criteria have been met: the books were made in Asia AND Wiley did not authorize his importing them $\left(9^{\text {th }}\right.$ Circuit precedent).

Librarians and educators are especially concerned about the loss of First Sale. Retailers and even charitable organizations such as Goodwill are also worried, since a copyrighted element (graphics, text, software) is part of a wide range of consumer

\footnotetext{
${ }^{19}$ Wiley vs. Kirtsaeng, p. 8, p. 6.
} 
items manufactured by American companies on foreign soil. The decision has broad implications for ownership of any material object in the U.S.

For us, who are interested in foreign-language media, it has the potential almost to reverse the great revolution in accessibility which the Internet has brought about, by restricting the circulation and Fair Use of physical media.

\begin{abstract}
About the Author
Judy Shoaf has a Ph.D. in French and Medieval Literature from Cornell. She has directed the Language Learning Center at the University of Florida since 1993. She maintains a website on copyright law \& educational media that can be accessed at http://www.clas.ufl.edu/llc/Copyright.
\end{abstract}

\begin{abstract}
About the Column
Legal Issues \& LLT is a column dedicated to examination of the legal considerations of copyright, fair use and ownership within the context of language teaching and learning.
\end{abstract}

